\title{
Degradability and flow rate studies in sheep fed a basal diet of Katambora Rhodes grass hay (Chloris gayana), supplemented with Silverleaf desmodium (Desmodium uncinatum)
}

\author{
KR Gono, JH Topps, NT Ngongoni, R Chihora \\ Department of Animal Science, University of Zimbabwe, PO Box MP 167, Mount Pleasant, Harare, Zimbabwe
}

The objective was to study the effects of supplementing Rhodes grass hay with a legume on digestion in ruminants. Two experiments were conducted with three rumen fistulated Holstein Friesian steers, and four rumen and abomasally cannulated wethers of the indigenous Sabi breed. Trial 1 was carried out to determine rumen degradability of dry matter (DM), neutral detergent fibre (NDF) and nitrogen (N). Trial 2 was to assess the flow of nutrients to the abomasum in sheep using the dual phase marker technique ; and to estimate microbial protein yield (MPY) using the purine derivatives $(P D)$ technique.

In trial 1 the diets used for both feeding the steers and in the nylon bags were: (a) the control, $100 \%$ Katambora Rhodes Grass Hay (KRGH), (b) $90 \% \mathrm{KRGH}$ supplemented with $10 \%$ Silverleaf desmodium (SL), (c) $80 \%$ $\mathrm{KRGH}+20 \% \mathrm{SL}$, (d) $70 \% \mathrm{KRGH}+30 \% \mathrm{SL}$. In trial 2 the diets used were (a) and (b) for assessing the flow of nutrients to the abomasum, and the estimation of MPY. For each diet the sheep received daily $1330 \mathrm{~g} \mathrm{DM}$ which was approximately $90 \%$ of ad libitum intake.

The results of trial 1 showed that the degradabilities of CP, DM and NDF were low in both the supplemented and control diets. They ranged from $56.8 \%$ to $57.4 \%$ for DM, $63.3 \%$ to $64.4 \%$ for $\mathrm{N}$ and $45.9 \%$ to $48.5 \%$ for NDF.

In trial 2 the flow of whole digesta to the abomasum of sheep averaged $7.71 \mathrm{~kg} /$ day and did not differ significantly between the two diets. There was an appreciable increase in the flow of nitrogen to the abomasum of sheep in the supplemented diet (11.9 vs $7.25 \mathrm{~g} \mathrm{~N} /$ day).

The MPY increased form $5.73 \mathrm{~g} \mathrm{~N} /$ day in the control diet to $9.46 \mathrm{~g} \mathrm{~N} /$ day in the $30 \%$ supplemented diet. The near doubling of MPY after supplementation indicated that SL can lead to an increased supply of either Rumen Degradable Nitrogen (RDN), fermentable energy, essential minerals, or a combination of these.

The conclusions drawn from the experiments were : (a) supplementation at the level of $30 \%$ SL slightly $(P<0.05)$ increased the degradability of dietary protein in the rumen, but there were no significant effects on the degradabilities of DM and NDF at this level ; (b) the $30 \% \mathrm{SL}$ level of supplementation also increased the flow of microbial protein to the abomasum. 